\title{
Membranous glomerulonephritis in rheumatoid arthritis unassociated with gold or penicillamine treatment
}

\author{
A HIGUCHI, Y SUZUKI, AND T OKADA \\ From the Department of Pediatrics, Faculty of Medicine, Toyama Medical and Pharmaceutical University, \\ Toyama, Japan
}

SUMMARY A 16 year old girl with rheumatoid arthritis who had not received gold or penicillamine developed a nephrotic syndrome. Her renal biopsy specimen showed membranouș glomerulonephritis by light, electron, and immunofluorescence microscopy.

Key words: nephrotic syndrome, subepithelial deposit(s), electron microscopy.

Gold $^{12}$ or penicillamine ${ }^{3+}$ treatment is well recognised to produce membranous glomerulonephritis (MGN) in patients with rheumatoid arthritis. MGN, however, is quite rare in the absence of administration of these drugs. It has recently been suggested that MGN is associated with rheumatoid arthritis independently of drug treatment, ${ }^{5}$ but others argue that this is unlikely.

We report a patient with MGN arising in rheumatoid arthritis without gold or penicillamine treatment.

\section{Case report}

A 16 year old girl was admitted to hospital on 9 September 1985 with heavy proteinuria and oedema. When evaluated at another hospital two years earlier she had had a strongly positive rheumatoid factor test and complained of migratory polyarthralgia. She had been diagnosed as having rheumatoid arthritis and was treated with aspirin and indomethacin, later changed to sulindac. She had first experienced facial oedema and proteinuria in April 1985. Thereafter she received oriental medicines and regular injections of methylprednisolone acetate intramuscularly once a week. Gold or

\section{Accepted for publication 16 December 1986}

Correspondence to $\mathrm{Dr} A$ Higuchi. Department of Pediatrics, Faculty of Medicine. Toyama Medical and Pharmaceutical University, 2630 Sugitani. Toyama 930-01, Japan. penicillamine had never been given before the admission.

Physical examination showed anasarca and weight $12 \mathrm{~kg}$ more than her usual. She had morning stiffness for up to two hours and also had joint pai $\bar{B}$ in the hands, elbows, and feet, and reduced range of motion of the right elbow with swelling. Radiơ? graphs showed no destructive lesion in the affected joints.

Laboratory studies showed a high sedimentatio rate of $170 \mathrm{~mm} / \mathrm{h}$, haemoglobin $104 \mathrm{~g} / \mathrm{l}$, norma white blood cell count, and thrombocytes. Tota serum proteins were $46 \mathrm{~g} / \mathrm{l}$, albumins $30.9 \%(14 \mathrm{~g} / 1)$ $\alpha 1$ globulins $3 \cdot 5 \%, \alpha 2$ globulins $42 \cdot 2 \%, \beta$ globulins $13.0 \%, \gamma$ globulins $10.5 \%$. Blood urea nitrogen was $11.4 \mathrm{mmol} / \mathrm{l}$, serum creatinine $61.9 \mu \mathrm{mol} / \mathrm{l}$, N吾. $138 \mathrm{mmol} / \mathrm{l}, \quad \mathrm{K} \quad 3.8 \mathrm{mmol} / \mathrm{l}, \quad \mathrm{Ca} 2 \mathrm{mmol} / \mathrm{l}$, $1.1 \mathrm{mmol} / \mathrm{l}$. Serum aspartate transaminase was $11 \mathrm{U}$ alanine transaminase $5 \mathrm{U}$, alkaline phosphatase $7 \cdot 4 \mathrm{KAU}$, cholesterol $12.6 \mathrm{mmol} / \mathrm{l}$, triglycerides $3.8 \mathrm{mmol} / \mathrm{l}$, uric acid $0.25 \mathrm{mmol} / \mathrm{l}$. Antistreptolysi通 O titre was 80. Lupus erythematosus test wæa negative. Latex test for rheumatoid factor was strongly positive, anti-DNA antibodies negative. $\mathrm{CH}$ was $680 \mathrm{mg} / \mathrm{l}, \mathrm{C} 4130 \mathrm{mg} / \mathrm{l}$. IgG $2.08 \mathrm{~g} / \mathrm{l}, \mathrm{IgA} 3.41 \mathrm{~g} /$ प् IgM 3.67 g/l. Hepatitis B surface (HBs) antigerf anti-HBs-antibodies, and a serological test for sypt ilis were all negative.

A 24 hour urine specimen contained $13 \mathrm{~g}$ protein with calculated creatinine clearance 


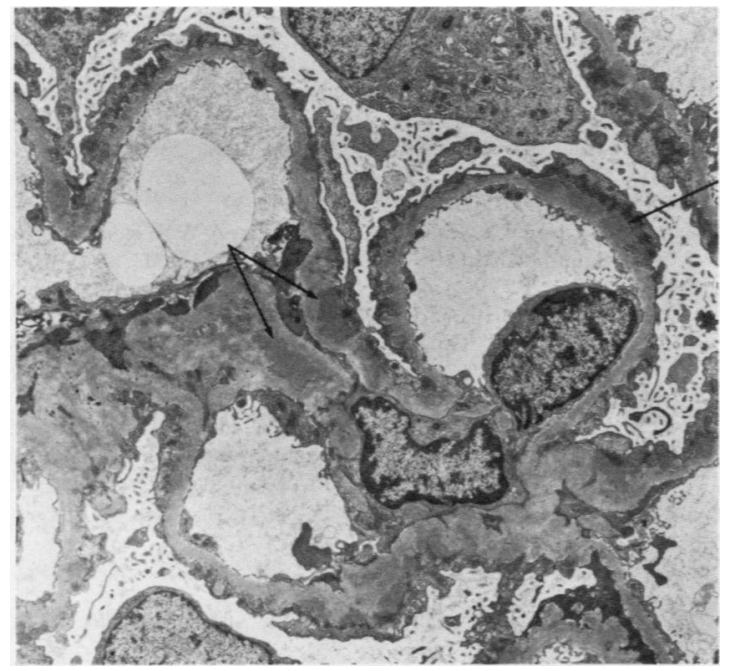

Fig. 1 Electron micrograph of the first renal biopsy specimen. Electron dense deposits are present in subepithelial sites with irregularity of the basement membrane.

$55.0 \mathrm{ml} / \mathrm{min}$. The sediment showed 5-10 red blood cells and white blood cells, and occasional granular casts per high power field.

The first renal tissue obtained on 9 October 1985 had few glomeruli, which were visible only in the Epon embedded material. Electron microscopy showed podocyte effacement. The glomerular basement membrane was thickened in a segmental pattern with subepithelial deposits (Fig. 1). There were no dense deposits in the mesangium.

The second renal biopsy performed seven months after the first one had 20 glomeruli. Optical microscopy showed neither cellular proliferation nor increase in the mesangial matrix. Focal tubular atrophy was present, accompanied by slight fibrosis. Immunofluorescence was strongly positive with IgG in a granular pattern, negative with IgA, and weakly positive with $\mathrm{C} 3$ and IgM along segmental loops. Electron microscopy showed irregularity of the basement membrane with subepithelial deposits of varying density, lucent areas, and thinner 'spikes' than previously.

\section{Discussion}

A diagnosis of rheumatoid arthritis in this patient was 'definite' by clinical and serological criteria, ${ }^{7}$ and membranous glomerulonephritis was proved by renal biopsy. The patient had received aspirin, indomethacin, sulindac, oriental medicines, and injections of methylprednisolone, but never gold or penicillamine. Though it is reported that nonsteroidal anti-inflammatory drugs induce lipoid nephrosis and interstitial nephritis, ${ }^{89}$ none of the administered drugs is known to cause MGN.

Recent studies of biopsy tissue have shown a variety of pathological changes in patients with rheumatoid arthritis. Mesangial alterations consisting of increased matrix or hypercellularity, or both, are most common, whereas MGN is distinctly rare in the absence of gold or penicillamine treatment. This lesion was not found in the studies by Salomon et al, ${ }^{10}$ Hordon et al, ${ }^{11}$ or Sellars et al, ${ }^{6}$ except related to gold or penicillamine treatment. Samuels et al reported eight patients with rheumatoid arthritis, two of whom had not received gold or penicillamine, and suggested that MGN was a feature of rheumatoid disease. ${ }^{5}$ Sellars et al, however, point out the possibility of overlap with lupus erythematosus because of positive antinuclear factors (ANF). ${ }^{6}$ MGN with positive ANF was seen in a patient studied by Friedman et al. ${ }^{12}$ In our case also there is a possibility of lupus because of the fact that some patients with apparently idiopathic MGN may later develop the full syndrome of lupus, and the fact that not all patients with lupus have a positive ANF.

There are a few reports in which MGN occurred in a patient with rheumatoid arthritis not treated with gold or penicillamine. Row et al described a patient with rheumatoid arthritis in whom MGN onset was unrelated to ingestion of non-steroidal anti-inflammatory drugs. ${ }^{13}$ Though details of treatment with gold or penicillamine were not given, MGN was also recognised in the study of Brun $e t$ al. ${ }^{14}$ Other reports have been made by Figueroa and Waxman ${ }^{15}$ and Evers et al. ${ }^{16}$

More recently Helin et al reported nine rheumatoid patients with MGN, one of whom had never received gold or penicillamine. ${ }^{17}$

Although it is obscure why MGN is so rare in rheumatoid arthritis, the possibility of coincidental occurrence of idiopathic MGN and rheumatoid arthritis in patients, including our case, seems small. We support the hypothesis that rheumatoid disease is causally related to MGN.

\section{References}

1 Silverberg D S. Kidd E G. Shnitka T K. Ulan R A. Gold nephropathy. A clinical and pathologic study. Arthritis Rheum 1970): 13: 812-25.

2 Husserl F E. Shuler S E. Gold nephropathy in juvenile rhcumatoid arthritis. Am J Dis Child 1979; 133: 50-2.

3 Dische F E. Swinson D R. Hamilton E B D. Parsons V. Immunopathology of penicillamine-induced glomerular discasc. $J$ Rheumatol 1976; 3: 145-54.

4 Ross J H, McGinty F, Brewer D G. Penicillamine nephropathy Nephron 1980; 26: 184-6. 
5 Samuels B. Lee J C. Engleman E P. Hopper J. Membranous nephropathy in patients with rheumatoid arthritis: relationship to gold therapy. Medicine (Baltimore) 1977: 57: 319-27.

6 Sellars L, Siamopoulos K. Wilkinson R, Leohapand T, Morley A R. Renal biopsy appearance in rheumatoid disease. Clin Nephrol 1983; 20: 114-20.

7 Ropes M W. Diagnostic critcria for rheumatoid arthritis. 1958 revision. Ann Rheum Dis 1959: 18: 49-53.

8 Finkelstein A. Fraley D S, Stachura I. Feldman H A. Gandy D R. Bourke E. Fenoprofen nephropathy: lipoid nephrosis and interstitial nephritis. A possible T-lymphocyte disorder. Am J Med 1982; 72: 81-7.

9 Clive D M. Stoff J S. Renal syndromes associated with nonsteroidal antiinflammatory drugs. $N$ Engl J Med 1984: 310: $563-72$.

10 Salomon M I. Gall G. Poon T P. Goldblat M V. Tchertkoff V. The kidney in rheumatoid arthritis. Nephron 1974: 12: 297-310.

11 Hordon L D. Sellars L. Morley A R. Wilkinson R. Thompson
M. Griffiths I D. Hacmaturia in rheumatoid arthritis: a ap̣. association with mesangial glomerulonephritis. Ann Rheum D 1984: 43: 440)-3.

12 Friedman R. Gallo G R. Buxbaum J N. Renal disease rheumatoid arthritis. Arthritis Rheum 1980): 23: 781-3.

13 Row P G. Cameron J S. Turner D R. et al. Membranou nephropathy. $Q$ J Med 1975: 44: 207-39.

14 Brun C. Olsen T S. Raaschou F. Sorensen A W S. Renal biops in rhcumatoid arthritis. Nephron 1965: 2: 65-81.

15 Figueroa J E, Waxman J. Membranous nephropathy rheumatoid arthritis. South Med J 1982: 75: 48(1-2.

16 Evers J. Statz T. Dickmans H A, Renner E. Membranous glomerulonephritis in rheumatoid arthritis unrelated to gold (क्f penicillamine treatment. Clin Nephrol 1985: 24: 159.

17 Helin H. Korpela M. Mustonen J. Pasternack A. Mi mesangial glomerulopathy-a frequent finding in rheumato arthritis patients with hematuria or proteinuria. Nephron 1986 42: $224-30$. 